\title{
Miejsce i rola kobiety $w$ rodzinie na przestrzeni wieków. Od Antyku po I wojnę światowa. Zarys problematyki
}

$\mathrm{O}$ BSZAREM NAUKOWYCH DOCIEKAŃ, który cieszy się coraz większym zainteresowaniem zdaje się być tematyka traktująca o społeczno-kulturowej tożsamości płciowej - gender studies. Jedną z wielu badanych przez naukę, powstałą na gruncie drugiej fali feminizmu, kwestii pozostaje pozycja i miejsce kobiet w społeczeństwie i kulturze. Specyficzna rola przypadła niewiastom w rodzinie.

Rodzina bez wątpienia stanowi podstawową komórkę społeczną, której funkcjonowanie, zwłaszcza w okresie kryzysu, stało się istotnym problemem. Jako kategoria historyczna nie pozostaje ona obojętna na upływający czas, podlegając jego prądom. Rodzina stanowi przedmiot analizy psychologów, socjologów, demografów, pedagogów. Historycy zainteresowali się tą tematyką stosunkowo późno, bo dopiero w XX wieku. Należy więc zgodzić się z postulatami, iż dopiero wieloaspektowa analiza rodziny ukaże mechanizmy rozwoju ludnościowego i społecznego ${ }^{1}$.

Korzeni współczesnego definiowania pojęcia rodzina szukać możemy u progu epoki nowożytnej. Socjologia rodziny będąc kierunkiem badań socjologii ogólnej zajmuje się w swych studiach rodziną jako grupą oraz instytucją społeczną. W orbicie jej zainteresowań znajduje się także wewnętrzna struktura rodziny wraz z procesami, które ją determinują. Socjologia rodziny bada również relacje dwustronne badanej struktury społecznej w kontekście społeczeństwa globalnego. Kwestia rodziny znalazła także poczesne miejsce w pedagogice, która koncentruje się w dużej mierze na funkcji socjalizacyjnej i wychowawczej rodziny. Jest ona przecież, również w obecnych czasach, jedną z najważniejszych instytucji wychowawczych dzieci i młodzieży.

${ }^{1}$ I. Gieysztorowa, Rodzina staropolska $w$ świetle badań demograficznych. Zarys problematyki, [w:] Społeczeństwo staropolskie, t. 2., red. A. Wyczański, Warszawa 1979, s. 159. 
Rodzina stawia przed sobą bardzo ciężkie i odpowiedzialne zadanie wprowadzenia dziecka w świat kultury i życia społecznego.

Demografia, choć początkowo rozwinięta i skoncentrowan na tendencjach rozwojowych populacji, z czasem stała się nauką bardzo istotną dla badań nad historią rodziny. Rozwinięta po II wojnie światowej francuska szkoła demografii wyposażyła historyków w niezbędne narzędzia służące mierzeniu zmian w populacji, ruchliwości, płodności czy modelów małżeństwa. W rozwoju studiów nad historią rodziny, będących interdyscyplinarnym polem naukowym, znaczącą rolę odegrała antropologia kulturowa. Leżące u podstaw antropologicznego podejścia założenie, iż rodzina ma charakter powszechny oraz, że wychowywanie dzieci jest łącznikiem pomiędzy indywidualnymi a dominującymi wartościami kultury, stało się nieodłącznym elementem wszystkich badań nad rodziną. Encyklopedyczna definicja rodziny głosi, iż rodzina jest podstawową komórką społeczną, a więc fundamentalnym i konstytutywnym elementem każdego społeczeństwa ${ }^{2}$. $\mathrm{Z}$ drugiej strony rodzina to również uniwersalna instytucja społeczna, utrwalona w tradycji wszystkich kultur „zrytualizowanym zespołem działań ludzkich ukierunkowanym na zaspokajanie określonych potrzeb swoich członków"3.

Wagę i znaczenie rodziny dostrzegali już starożytni. Jeden z najwybitniejszych filozofów, Arystoteles, uwypuklał jej rolę zaznaczając, iż „każde bowiem państwo składa się z rodzin” 4 . Ta stanowi więc najmniejszą, konieczną do dalszej ewolucji cząstkę. O kluczowym miejscu rodziny w Polis, choć reprezentując diametralnie inne stanowisko pisał Platon, dla którego idealne państwo pozbawione jest życia rodzinnego a dzieci są własnością państwa, które dba o ich wychowanie ${ }^{5}$. W starożytnej Grecji kobieta miała ograniczone prawa, także w rodzinie. Obowiązywał ją zakaz opuszczania rodzinnego domu aż do momentu zamążpójścia. Gdy odbył się już ślub, rola wybranki sprowadzała się do prowadzenia domu, wyrobu tkanin czy wychowania dzieci, co było kluczowym elementem funkcjonowania społeczności Polis ${ }^{6}$. Myśl grecką rozwinęli i wzbogacili Rzymianie, dla których kluczową

${ }^{2}$ Encyklopedia Socjologii, t.3., red. Z. Bokszański, A. Kojder, Warszawa 200o, s. 312.

${ }^{3}$ Ibidem, s. 313.

${ }^{4}$ Arystoteles, Polityka, Warszawa 2008, s. 28.

${ }^{5}$ M. Cytowska, H. Szelest, Historia literatury starożytnej, Warszawa 2006, s. 81.

${ }^{6}$ S. Stabryła, Zarys kultury starożytnej Grecji i Rzymu, Warszawa 2007, s. 76. 
rolę odgrywał w rodzinie ojciec - pater familias 7 . Choć miał on niemal absolutną władzę, obligatoryjny był obowiązek zasięgania przez niego rady w wypadku chęci podjęcia jakiegokolwiek działania. Zwoływał więc on „rodzinne consilium”, na którym konsultował się z matką czy siostrą ${ }^{8}$. Z upływem lat władza ojcowska ulegała stopniowemu osłabieniu, a kobieta zaczęły mieć większy, choć nadal skromny, wpływ na zarządzanie gospodarstwem domowym i wychowanie dzieci ${ }^{9}$. Małżeństwo miało w Rzymie charakter monogamiczny. Jak pisał Modestyn - był to związek mężczyzny i kobiety na całe życie, wspólnota prawa boskiego i ludzkiego ${ }^{10}$. Dla naszych rozważań istotniejszym jest jednak proces indywidualizacji swobód poszczególnych członków rodziny zwłaszcza kobiet, które u schyłku Cesarstwa Rzymskiego mogły nawet samodzielnie dysponować własnością rodzinną ${ }^{11}$. Istotną kwestią jest, przełomowe pod wieloma względami, prawodawstwo Oktawiana Augusta, które nakazywało kobietom pozostanie w małżeństwie od 20 do 50 roku życia. Po rozwodzie lub śmierci małżonka mogły one przeciągnąc rozpoczęcie nowego związku odpowiednio o 18 miesięcy lub 2 lata $^{12}$.

Tradycja judeochrześcijańska traktowała kobietę jako własność mężczyzny - najpierw ojca, później męża, „on zobowiązany był zapewnić jej utrzymanie" ${ }^{13}$. Biblijne spojrzenie na kobietę zaważyło na jej późniejszym postrzeganiu, głównie w epoce wczesnego średniowiecza. Biblijna Ewa stała się więc uosobieniem niewiast, nie tylko dla filozofów ale także i teologów. Obraz kobiety wczesnego średniowiecza przesiąknięty był złym wizerunkiem, w którym podkreślano negatywne cechy kobiecej osobowości, moralności, charakteru czy natury ${ }^{14}$. Nieco inaczej rzecz się miała pośród społeczeństw słowiańskich, które do kobiet odnosiły się z dużym szacunkiem ${ }^{15}$. W germańskim prawodaw-

${ }^{7}$ S. Litak, Historia wychowania, t. 1.: Do wielkiej Rewolucji Francuskiej, Kraków 2005, s. 38.

${ }^{8}$ M. Crawford, Rzym w okresie Republiki, Warszawa 2004, s. 35.

${ }_{9}$ S. Stabryła, Zarys..., op. cit., s. 174.

${ }^{10}$ R. Krajewski, Prawa i obowiązki seksualne małżonków, Warszawa 2009, s. 50.

${ }^{11}$ Ibidem, s. 51.

${ }^{12}$ W. Dajczak, T. Giaro, F. Longchamps, Prawo rzymskie. U podstaw prawa prywatnego, Warszawa 2009, s. 229-230.

${ }^{13}$ M. Babik, Stownik biblijny. Małżeństwo - rodzina - seksualność, Kraków 2009, S. 110.

${ }^{14}$ Z. Majchrzyk, Kiedy kobieta zabija, Warszawa 2009, s. 28; M. Alexandre, Early Christian Women, [w:] A history of women in the West: From ancient goddes to Christian saints, red. G. Duby, M. Perrot, Harvard 2002, s. 409.

${ }_{15}$ Por. Z. Kuchowicz, Obyczaje staropolskie XVII-XVIII wiek, Łódź 1975, s. 145-146. 
stwie była ona postrzegana jako istota nie potrafiąca zadbać o swoje własne interesy. Takim przykładem było np. prawo lombardzkie, które nawet dorosłą kobietę pozostawiało pod opieką mężczyzny ${ }^{16}$.

Przyjęcie chrztu przez Mieszka I w roku 966 pociągnęło za sobą, oprócz reperkusji politycznych, zmiany w istniejących do tej pory relacjach wewnątrz rodzinnych. Pozycja kobiety zbliżyła się do miejsca i roli zarezerwowanej dla mężczyzn. „Kobieta i mężczyzna odtąd mieli być różnymi, ale równymi pod względem praw i obowiązków towarzyszami życia" ${ }^{17}$. Stopniowo zaczęto zdawać sobie sprawę, iż córki pełnić mogą całkowicie nową rolę w realizacji dążeń dynastycznych i politycznych ${ }^{18}$. Kobieta miała jednak utrudniony dostęp do wielu zawodów czy zajęć. Często spotykanym była odmowa córkom czy żonom, prawa do nauki ${ }^{19}$. W zestawieniu z antykiem, liczba kobiet piszących w średniowieczu jest zdumiewająca. Należy to tłumaczyć rosnącą rolą kościoła, bowiem duża liczba kobiet w klasztorach uczyła się pisać i czytaćc $^{20}$. Uczeni zajmujący się w swych studiach historią kobiet na ogół zgodni są w kwestii zauważalnego wzrostu ich znaczenia w okresie wieku XII-XIII. W tym czasie w szerokim kręgu chrześcijaństwa pojawiły się kobiety, które wyniesione zostały na ołtarze. Równocześnie na obszarze polskim spotykamy „białogłowe” otoczone coraz większą czcią - Jadwiga von Andechs, małżonka księcia śląskiego Henryka Brodatego, kanonizowana w 1267 r; Salomea, córka Leszka Białego; Kinga-Kunegunda, córka króla Węgier Beli IV ${ }^{21}$. W epoce Średniowiecza ojciec stanie się jednak pewnikiem stabilności rodziny a przez to i państw jako całości. W tym okresie uznanym za prawowitego ojca była ta osoba, która była małżonkiem. Jak pisze Anna Szulc: „w tamtym systemie nie wola ojca czy rodziców decydowała o ojcostwie, ale bycie mężem” ${ }^{22}$. W Średniowieczu rola społeczna nie zawsze szła w parzę z rolą biologiczną mężczyzn oraz kobiet. Wielokrotnie zdarzało się, że to mężczyzna zajmował miejsce ko-

${ }^{16}$ D. Herlihy, Land, Family, and Women in Continental Europe, 701-1200, [w:] Women in medieval society, red. B. Bolton, S. Stuard, Pennsylvania 1976, s. 14.

${ }_{17}$ D. Pauluk, Modele ról kobiety $w$ podręcznikach do wychowania seksualnego, Kraków 2005, s. 14 .

${ }^{18}$ Por. L. E. Mitchell, Family life in the Middle Ages, Westport 2007, s. 10.

${ }^{19}$ M. Bogucka, Białogłowa $w$ dawnej Polsce, Warszawa 1998, s. 169.

${ }^{20}$ M. Aquilina, C. Bailey, Tajemnica Graala, Kraków 2008, s. 68.

${ }^{21} \mathrm{M}$. Weber, Żywoty świętych jako źródto informacji o kontaktach dynastycznych węgiersko-polsko-turyngskich, [w:] Nasze Historie, t. 7., (2002), Poznań 2005, s. 37.

${ }_{22}$ A. Szulc, Ojciec $w$ mrokach Średniowiecza, [w:] Przekrój, 37/2008, http://www. przekroj.pl/wydarzenia_kraj_artykul,2776.html, 2.05.2009 r. 
biety opiekując się dziećmi ${ }^{23}$. Istotne dla niniejszych rozważań rozróżnienie wprowadza Jennifer Ward. W swojej pracy poświęconej kobiecie w średniowiecznej Europie zaznacza, iż jej funkcje zależne były od charakteru rodziny męża. I tak oto w rodzinach nuklearnych, małżeństwo oznaczało stabilizację i otwierało nowe możliwości rozwoju, niejednokrotnie jednak zdarzało się tak, że małżonka trafiała do familii, dużej rodziny skupiającej pod jednym dachem trzy lub więcej pokoleń. Wtedy to na pierwszy plan wysuwała się teściowa, a znacznie małżonki równe było funkcji służącej ${ }^{24}$. Trudno również zgodzić się z przekonaniem, iż wszystkie małżeństwa aranżowane były przez ojców lub władców. Poniżej pewnej uprzywilejowanej warstwy społecznej zdarzały się małżeństwa, które były wynikiem świadomego wyboru dokonanego przez mężczyznę oraz kobietę ${ }^{25}$. O rosnącej roli kobiety-żony świadczyć może relacja włoskiego dyplomaty opisującego zwyczaje angielskie w 1497 roku. Dostrzega on, iż w razie śmierci, mężczyzna przekazuje majątek swojej żonie, wyłączając zupełnie z procedury spadkowej dzieci. Wdowa natomiast może również zignorować potomstwo wybierając męża spośród służby ${ }^{26}$. Kwestia posagu uregulowana była prawnie. Kobieta wychodząca za mąż dostawała go od swojego ojca. Stanowił on część, którą wnosiła ona do gospodarstwa. Posag stanowił więc część spadku ${ }^{27}$. Jak podaje Włodzimierz Dworzaczek, „pozycja społeczna rodziny żony była nader ważna ze względów zarówno majątkowych jak koligacyjnych dla pozycji przyszłego potomstwa" ${ }^{28}$.

Zwołany przez papieża Pawła III sobór w Trydencie, prowadzony w latach 1545-1563, zmienić miał nie tylko oblicze kościoła ale i przewartościować miał dotychczasowe normy i wzorce. Dla rozważań o rodzinie oraz o roli jaką pełnił w niej ojciec najważniejsze była treść doktryny o małżeństwie. Jej treść ustalona została 11 listopada $1563 \mathrm{r}$.

${ }^{23}$ Medieval memories: men, women and the past, 700-1300, red. E. Van Houts, Essex 2001, s. 3.

${ }^{24}$ J. Ward, Women in medieval Europe, 1200-150o, Essex 2002, s. 45.

${ }^{25}$ Więcej: S. McSheffrey, Marriage, sex, and civic culture in late medieval London, Pennsylvania 2006, s. 78.

${ }^{26}$ An account of England by an Italian visitor, [w:] Women in England, c. 12751525: documentary sources, red. P. J. Goldberg, Manchaster 1995, s. 133.

${ }^{27}$ K. Ratajczak, Edukacja kobiet $w$ kręgu dynastii piastowskiej $w$ średniowieczu, Poznań 2005, s. 23.

${ }^{28}$ W. Dworzaczek, O badaniach genealogicznych nad dawna rodzina, [w:] Spoteczeństwo staropolskie. Studia i szkice, red. A. Wyczański, Warszawa 1979, s. 179. 
na 24 sesji soboru ${ }^{29}$. Mówiła ona, iż rodzina jako jedność nie spełnia w całości swego posłania bez obecności w niej ojca. W polskiej rzeczywistości wiek XVI to silna władza ojca oraz rola kobiet przejawiająca się $\mathrm{w}$ prowadzeniu gospodarstwa domowego oraz przez wychowanie dzieci, w myśl powiedzenia „bo nie żona męża, ale mąż żonę oszlachca"so.

Model ojcostwa zacznie ulegać jednak przemianom a postać samego ojca stanie się w XVII w. początkiem nowego pojęcia rodziny ${ }^{31}$. Od XVII wieku obserwujemy „ojca, który powierza matce troskę o kierowanie stołem" ${ }^{2}$. Dotychczasowa głowa rodziny zacznie powoli przeistaczać się w ojca-opiekuna, którego zadaniem będzie przekazywać zstępnym bliskie mu poglądy. Epoka Renesansu niosła ze sobą liczne zmiany dotyczące pozycji kobiety w rodzinie. Wkroczyła ona do polityki i życia towarzyskiego wykraczającego poza jej dom. Jak zaznacza Urszula Augustyniak: „przełamano stereotyp niższości intelektualnej kobiet, które brały aktywny udział w dysputach teologicznych, a w ciągu XVII wieku zdobywały w coraz większym zakresie prawo do edukacji”33. „Białogłowa” więc zacznie zmierzać do pełnienia coraz większej roli w społeczeństwie, jak zaznacza Zbigniew Wójcik - roli samodzielnej ${ }^{34}$. Pożycie małżeńskie społeczeństwa staropolskiego charakteryzowała większa niż dziś obojętność i egoizm ${ }^{35}$.

Społeczna rola kobiety przeszła jednak kolejne stadia ewolucji. Matka stała się „pierwszym nauczycielem, pokazującym i wyjaśniającym tajemnice życia, formułującym zakazy i nakazy, wprowadzającym w świat norm i zasad"36. Podobnie jak w wiekach wcześniejszych kobiety wchodziły w związek małżeński głównie z przedstawicielami

${ }^{29}$ Więcej: K. Schatz, Sobory powszechne - punkty zwrotne $w$ historii Kościoła, Kraków 2001; L. Ranke, Dzieje papiestwa $w$ XVI-XIX $w$, Warszawa 1981; S. Głowa, I. Bueda, Breviarium Fidfei. Wybór doktrynalnych wypowiedzi Kościoła, Poznań 2000; A. Baron, H. Pietras, Dokumenty soborów powszechnych, Kraków 2001-2004.

$3^{\circ}$ Odpowiedź Króla Zygmunta Augusta (1548), [w:] Wybór mów staropolskich świeckich, sejmowych $i$ innych, red. A. Małecki, Kraków 1860, s. 31.

${ }^{31}$ Ibidem, s. 224.

${ }^{32}$ Historia ojców i ojcostwa, red. J. Delumeau, D. Roche, Warszawa 1995, s. 224.

${ }_{33}$ U. Augustyniak, Historia Polski 1572-1795, Warszawa 2008, s. 320.

${ }^{34}$ Z. Wójcik, Historia powszechna XVI-XVII wieku, Warszawa 2001, s. 144.

${ }_{35}$ Z. Kuchowicz, Obyczaje..., op. cit., s. 214; J. Tazbir jest zdania, iż „w świetle tego co wynika ze źródeł, rodzina staropolska raczej mało nadaje się do idealizacji oraz stawiania jej za wzór współcześnie żyjącym Polakom”, J. Tazbir, Polska na zakrętach dziejów, Warszawa 1997, s. 171.

${ }^{36}$ M. Bogucka, Staropolskie obyczaje w XVI-XVII wieku, Warszawa 1994, s. 67. 
tej samej warstwy społecznej. Dla późnego średniowiecza charakterystycznym stały się ostrzejsze przepisy prawne, które miały za zadanie regulowanie spraw zawierania małżeństw poza obrębem własnego stanu ograniczając małżeństwa szlachecko-mieszczańskie ${ }^{37}$. Kwerenda źródłowa przeprowadzona przez Irena Gieysztorową również dowodzi, iż społeczeństwo staropolskie charakteryzowało się kastowością oraz przewagą motywacji ekonomicznych nad uczuciowymi ${ }^{38}$.

Kluczowe dla naszych rozważań wydarzenia miały miejsce w 1807 roku. W tymże, na mocy traktatu z Tylży, powstało Księstwo Warszawskie. Konstytucja tego nowego podmiotu z 22 lipca 1807 r. wprowadzała na terenach Księstwa nową sytuację prawną. Konstytucja oparta była na francuskim kodeksie cywilnym z roku 1804. W ważki sposób kodeks ten reguluje pozycje kobiety $\mathrm{w}$ rodzinie. Tytuł V, pierwszej księgi zatytułowanej o małżeństwie głosi, iż wychowanie i utrzymanie dziecka spoczywa na obojgu małżonków (dział V, art. 203). Mąż natomiast winien jest zapewnić małżonce bezpieczeństwo (dział VI, art. 213) i „dostarczyć wszystkiego, co do życia potrzebne, podług swoiei możności i stanu" (dział VI, art.. 214) ${ }^{39}$. Stanowiło to jawne przeciwieństwo przeszłości, w której jeszcze stulecie wcześniej ojciec posiadał prawo do chłosty żony. Mógł je on stosować, gdy małżonka okazała się nieposłuszna lub gdy zaniedbywała dom ${ }^{40}$.

W XIX wieku „sprawami finansowymi zajmowała się z reguły matka, na której barkach spoczywał ogrom obowiązków związanych z prowadzeniem domu i wychowaniem dzieci" ${ }^{41}$. Jak zauważa Claudia Kraft w republice szlacheckiej istniało równouprawnienie kobiet reprezentujących ten sam stan. Było to powodem żywego uczestnictwa niewiast w życiu publicznym ${ }^{42}$.

${ }^{37}$ M. Koczerska, Rodzina szlachecka $w$ Polsce późnego średniowiecza, Warszawa 1975, s. 20.

${ }^{38}$ I. Gieysztorowa, Rodzina..., op. cit., s. 164-166.

39 Dokument dostępny pod adresem: http://www.wbc.poznan.pl/dlibra/doccontent?id=77369\&dirids $=1,20.12 .2010 \mathrm{r}$.

40 Por. A. Zadrożna, Przemoc wobec kobiet, http://zowmlawa.home.pl/przemoc\%20wobec\%2okobiet.doc, 03.05.2009 r.

${ }^{41} \mathrm{~W}$. Korzeniowska, Edukacja i wychowanie różnych warstw społecznych na ziemiach polskich - od drugiej połowy wieku XIX do roku 1918, Kraków 2004, s. 66.

${ }^{42}$ C. Kraft, Państwo wobec rodziny - polityka państw europejskich $w$ XIX i XX wieku, s. 12, tekst dostępny pod adresem: http://jazon.hist.uj.edu.pl/zjazd/materialy/ kraft.pdf, 30.12.2010 r. 
Oddając głos źródłom, również dowiadujemy się o znaczącej roli kobiet w życiu rodziny. Julian Wieniawski w swym pamiętniku umieścił: „cały ciężar wychowania spadał na nieocenioną naszą Matkę [...] Ona nauczyła nas czytać i pisać"43. Leon Król pisał natomiast w swych wspomnieniach: „pod opieką Matki chowałem się do czternastu lat”44.

Położenie kobiet w XIX wieku poruszały liczne ruchy feminsistyczne. Interesującym jest, iż szukały one przede wszystkim równości wobec prawa i donioślejszego wpływu na wychowanie potomstwa. Niewiele natomiast z nich walczyło o równość pomiędzy mężem a żoną ${ }^{45}$. Wyjątkiem może być Marion Reid, która mniej więcej w połowie stulecia pisała, iż należy odejść od modelu, w którym to mąż ma absolutną władzę, nie tylko nad małżonką, lecz również i nad jej majątkiem i dziećmi ${ }^{46}$.

W czasie trwania XIX stulecia, dla różnych warstw społecznych, rodzina pełniła odmienne funkcje. Model ten poddany był w następnym, XX stuleciu, licznym transformacjom. Pierwsze znaczące zmiany nastąpiły po I wojnie światowej. Obecność mężczyzn na frontach toczącej się wojny stała się przyczyną zwrotu samodzielności wśród kobiet. Stanęły one w obliczu nowych wyzwań i funkcji. W okresie dwudziestolecia międzywojennego kobiety dążyły do zrównania ich statusu ze statusem mężczyzny.

\section{SUMMARY}

FOR A LONG TIME, history of women was not in the mainstream of interest. The interest for this topic was not shown untill the twentieth century. The aim of this paper is to present a long and difficult struggle to gain the status similar to the one women have nowadays. It is difficult to understand the present reality without going back to the past. The role of women is undergoing a lot of changes all the time. This subject is a huge field for research. The article attempts to give a summary of publications which deal with women's issues.

${ }^{43}$ J. Wieniawski, Kartki z mego pamiętnika, t. 1., Warszawa-Kraków 1911, s. 1.

${ }^{44}$ L. Król, Wspomnienia dotyczące powstania z 1863r., Kórnik 1911, s. 2.

45 Por. M. Carden, The complexity of the relationship between the family, society, and women 's status, [w:] Women and the family: two decades of change, red. B. Hess, M. Sussman, New York-London 1984, s. 11.

${ }^{46}$ M. Walters, Feminism: a very short introduction, Oxford 2005, s. 42-43. 
NOTA O AUTORZE

Rafał Kamprowski [rafal.kamprowski@amu.edu.pl] absolwent Wydziału Historii Uniwersytetu im. Adama Mickiewicza w Poznaniu. W 2010 roku ukończył Stosunki Międzynarodowe na Wydziale Nauk Politycznych i Dziennikarstwa UAM w Poznaniu w stopniu licencjata. Obecnie doktorant na tymże wydziale. Przewodniczący Koła Naukowego Historii Najnowszej przy WNPiD UAM w Poznaniu. 
